\title{
The Role of Honeybee Workers on Fruit Set and Their Characteristics in Some Plum Varieties
}

Abd Al-Fattah, M. A. ${ }^{1}$; I. E. Elshenawy ${ }^{2}$; E. E. Tharwat ${ }^{3}$ and Sarah H. El-Dereny ${ }^{3}$ 1.Department of Economic Entomology \& Pesticides, Faculty of Agriculture, Cairo University, Giza, Egypt.

2. Department of Pomology, Faculty of Agriculture, Cairo University, Giza, Egypt

3. Department of Beekeeping, Plant Protection Institute, Agriculture Research Center, Ministry of Agriculture, Giza, Egypt.

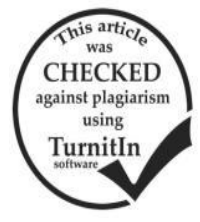

\begin{abstract}
The present study was carried out on three plum cultivars; Golden Japanese, Hollywood and Santarosa during two successive seasons 2012 and 2013 to study the influence of different pollination treatments on fruit set and fruit characteristics of the studied cultivars. Several sequential treatments were applied from 1 bee visit/ flower up to ten bee visits/ flower besides zero visit (self-pollination/ control) and open pollination treatments. The relationship between the foraging activity of honeybees in cross-pollinated flowers of plum cultivars and both fruit set and the main fruit characteristics were investigated. Bee foragers expressed significant benefit to plum cultivars on final fruit set as well as on fruit characteristics; length, diameter, T.S.S. \%, fruit weight and volume and improved fruit quality through decreasing fruit firmness.Results of the present study showed direct improvements as a result of increased bee visits/ flower which were reflected on significant increase in fruit set when comparing self-pollination with open insect pollination. Results were $18.7 \%, 86.7 \% ; 27.5 \%, 95.7 \% ; 28.6 \%, 91.3 \%$ for season 2012 and $19.7 \%, 87.5 ; 26.9 \%, 96.0 \% ; 26.1 \%, 94.7 \%$ for season 2013 , for the three studied cvs., respectively.Moreover, fruit characteristics showed positive effects of increasing bee visits/ flower were expressed as significant improving in fruit weight which averaged $19.93 \mathrm{~g}, 27.10 \mathrm{~g}, 28.16 \mathrm{~g}$ for studied plum cvs., respectively, as a result of zero bee visit/ flower and continued its significant improving to reach $84.00 \mathrm{~g}, 95.75 \mathrm{~g}, 89.97 \mathrm{~g}$ for open bee visits/ flower in season 2012. Similar trend was observed for season 2013.Consequently, significant improvements in fruit volume, fruit length, diameter, T.S.S. $\%$ and firmness were recorded and presented. Thus, it can be recommended from results of the present study to maintain sufficient honey bee colonies in Golden Japanese, Hollywood and Santarosa plum orchards that offer at least ten bee visits/ flower to increase fruit set and to achieve satisfactory improvement in yield and fruit characteristics.
\end{abstract}

Keywords: plum, pollination, honeybee, fruit set, fruit characteristics.

\section{INTRODUCTION}

Plum belongs to the Rosaceae family; most commercial plum varieties grown in Egypt are either totally or partially self-unfruitful and require crosspollination to produce commercial crops. Unsatisfactory crop yield from Plum has been traced to insufficient or ineffective pollination. It is important to ensure that suitable varieties with similar blossoming periods are planted throughout the orchard to ensure that there is adequate pollen variation for cross pollination (Abdelaziz, et al., 2005 and Hassan et al., 2007).

Pollen of many stone fruit species is too heavy to be carried by wind in sufficient quantities to produce a good set. Thus, insects foraging in flowers for pollen (their protein source) and nectar (their calorie source) must be relied on to carry most of the pollen. Honeybees (Apis mellifera) are the most important pollinators for plums (Free, 1993; Calzoni and Speranza,1996; 1998; Delaplane and Mayer, 2000 and Guerra and Rodrigo, 2015) and several studies have demonstrated an apparent relationship between the number of honeybees and the fruit quality of crop which are particularly important characteristics when fruits are to be consumed fresh (Stern et al., 2001; Hassan et al., 2007 and Guerra, 2010).

The duration of flowering of a specific tree can vary from one week to several weeks. To set satisfactory commercial crops on plum varieties needing pollinators, varieties must bloom at the same time, be cross compatible, and provide adequate pollen capable of setting fruit (Guerra and Rodrigo, 2015).

The objective of this study was to evaluate the effect of different pollination treatments on productivity and fruit quality of three plum cultivars that are the most commonly grown in Egypt.

\section{MATERIALS AND METHODS}

The current investigations were carried out in plum orchards at Elkalubia Government, during the two successive seasons 2012, 2013 on mature trees (20 years old) of Golden Japanese, Hollywood and Santarosa cvs. Trees were planted in a clay loamy soil and were of uniform growth. Trees were spaced at $4 \times 5 \mathrm{~m}$. and planted in rows where the cvs. alternated with each other. The study focused on the effect of visiting numbers with honeybees on fruit characteristics.

Pollination treatments on plum cultivars flowers.

This point was adopted by selecting five trees from each cv. and each tree was considered a replicate. Twelve pollination treatments were carried out on flowers and each treatment was conducted by selecting forty clusters in each cvs. which were distributed uniformly on different parts of each of the five replicate trees.

The flowers of each cluster were eliminated to the king flower after removing the other lateral flowers (thinning). The selected flowers were bagged and labeled at full pink stage. Flowers were covered with pergamin pollination bags; which allow flowers to receive sunlight and prevent any outside pollinators. Another group of flowers were left uncovered and served as open pollination treatment, which received pollen from all available pollen vectors.

At full bloom, pergamin bags were temporarily removed from each selected group of flowers on the replicate trees one by one and subjected to the following 
pollination treatments through honeybee visits as follows:

a. 0 bee visits/ flower (self-pollination treatment): selected flowers at full pink stage were enclosed in pergamin bags to prevent pollen transfer from another flower. Bags were removed when stigmas became completely dry.

b. 1 bee visit/ flower.

c. 2 bee visits/ flower.

d. 3 bee visits/ flower.

e. 4 bee visits/ flower.

f. 5 bee visits/ flower.

g. 6 bee visits/ flower.

h. 7 bee visits/ flower.

i. 8 bee visits/ flower.

j. 9 bee visits/ flower.

k. 10 bee visits/ flower.

1. Open bee visits/ flower.

After the required number of bee visits occurred, bags were replaced immediately to prevent contamination by any extra unrequired pollen. Pergamin bags were removed when stigma dried and petals fell.

\section{Measured parameters}

\section{Percentage of fruit set}

The percentage of final fruit set was determined in plum cvs. for all previously mentioned pollination treatments by applying the following formula:

Fruit set $\%=$ (number of fruits/ number of flowers) $x 100$

\section{Fruit characteristics}

At harvest, fruits resulting from the different pollination treatments were collected at maturity. The influence of each pollination treatment on Golden Japanese, Hollywood and Santarosa cvs. fruit characteristics was determined by measuring the following parameters:

a. Fruit length (cm.).

b. Fruit diameter (cm.).

c. Fruit weight (g.).

d. Fruit volume $\left(\mathrm{cm}^{3}\right)$.

e. Fruit firmness (using a pressure tester, lb/ inch ${ }^{2}$ ).

f. Total Soluble Solids in fruit juice (T.S.S. \%) using a hand refractometer according to (AOAC, 1985).

\section{Statistical Analyses}

Experiments were designed in a randomized complete block design with five replicates; each tree was considered a replicate. Data were subject to the analysis of variance (ANOVA) according to Freed et al. (1989) using MSTAT software and means of treatments were compared using Duncan multiple range test (1955) at a significance level of 0.05 .

\section{RESULTS AND DISCUSSION}

\section{Final fruit set \%:}

Table (1) shows that the values of Fruit set percentages of three plum cultivars Golden Japanese, Hollywood and Santarosa under different numbers of pollination treatments during 2012 and 2013 seasons. The data reveal that fruit set percentage for Golden Japanese was positively correlated with the number of honeybee visits being $23.8 \%$ and $25.5 \%$ for 2012 and 2013, respectively, as a result of one bee visit/flower and significantly increased to $83.3 \%$ and $85.7 \%$ for 2012 and 2013, respectively, when the number of visits increased to 10 bees/ flower. Similarly, the similar trend of increase was observed for Hollywood and Santarosa cvs. At the maximum rate of increment (10 visits/ flower), the percentage of fruit set was significantly improved to $89.5 \%, 88.2 \%$ and $88.9 \%, 85 \%$,respectively.

Under open pollination conditions Hollywood gave the highest fruit set, $(95.7 \%$ and $96 \%$, respectively). It is evident that self-pollination ( 0 bees/ flower) gave the lowest fruit set percentage in all cultivars than all other treatments.

Results of the current investigation agree with the findings of (Langridge and Goodman 1985; Sapir et al., 2007; Stern et al., 2007; Guerra et al., 2010 and Guerra and Rodrigo, 2015) which indicated that increased bee activity in plum orchards leads to high yield and fruit set. El-Dereny, Sarah (2010) showed the similar effect with apple and almond fruits.

Table (1). Effect of number of bee visits/ flower on final fruit set of three Plum varieties during two successive seasons, (2012-2013).

\begin{tabular}{lcccccc}
\hline \multicolumn{2}{l}{ No. of bees/ Golden Japanese } & \multicolumn{2}{c}{ Hollywood } & \multicolumn{2}{c}{ Santarosa } \\
Flower & $\mathbf{2 0 1 2}$ & $\mathbf{2 0 1 3}$ & $\mathbf{2 0 1 2}$ & $\mathbf{2 0 1 3}$ & $\mathbf{2 0 1 2}$ & $\mathbf{2 0 1 3}$ \\
\hline 0 & $18.7 \%$ & $19.7 \%$ & $27.5 \%$ & $26.9 \%$ & $28.6 \%$ & $26.1 \%$ \\
1 & $23.8 \%$ & $25.5 \%$ & $33.3 \%$ & $31.6 \%$ & $31.1 \%$ & $32.7 \%$ \\
2 & $32.6 \%$ & $30.8 \%$ & $38.2 \%$ & $40.0 \%$ & $37.9 \%$ & $38.5 \%$ \\
3 & $37.5 \%$ & $36.1 \%$ & $48.0 \%$ & $47.8 \%$ & $45.0 \%$ & $46.4 \%$ \\
4 & $40.9 \%$ & $39.5 \%$ & $53.6 \%$ & $51.6 \%$ & $52.6 \%$ & $54.5 \%$ \\
5 & $47.1 \%$ & $44.8 \%$ & $60.0 \%$ & $63.0 \%$ & $60.6 \%$ & $63.2 \%$ \\
6 & $51.9 \%$ & $56.7 \%$ & $68.2 \%$ & $69.6 \%$ & $61.5 \%$ & $64.0 \%$ \\
7 & $60.0 \%$ & $63.6 \%$ & $77.3 \%$ & $78.9 \%$ & $66.7 \%$ & $65.0 \%$ \\
8 & $66.7 \%$ & $68.8 \%$ & $80.0 \%$ & $79.2 \%$ & $70.6 \%$ & $73.3 \%$ \\
9 & $76.2 \%$ & $75.0 \%$ & $84.2 \%$ & $85.0 \%$ & $76.5 \%$ & $81.8 \%$ \\
10 & $83.3 \%$ & $85.7 \%$ & $89.5 \%$ & $88.2 \%$ & $88.9 \%$ & $85.0 \%$ \\
open & $86.7 \%$ & $87.5 \%$ & $95.7 \%$ & $96.0 \%$ & $91.3 \%$ & $94.7 \%$ \\
\hline
\end{tabular}

\section{Fruit length and diameter $(\mathbf{c m}$.$) :$}

Data presented in Table (2) and (3) indicated that increasing honey bee visits to flowers yielded fruits with higher dimensions as compared with self-pollination $(0$ bee visits).

Table (2). Effect of number of bee visits/ flower on fruit length of three Plum varieties during two successive seasons, (2012-2013).

\begin{tabular}{lcccccc}
\hline \multicolumn{2}{l}{ No. of bees/ Golden Japanese } & \multicolumn{2}{c}{ Hollywood } & \multicolumn{2}{c}{ Santarosa } \\
Flower & $\mathbf{2 0 1 2}$ & $\mathbf{2 0 1 3}$ & $\mathbf{2 0 1 2}$ & $\mathbf{2 0 1 3}$ & $\mathbf{2 0 1 2}$ & $\mathbf{2 0 1 3}$ \\
\hline 0 & $1.95 \mathrm{j}$ & $2.03 \mathrm{k}$ & $2.12 \mathrm{~h}$ & $2.10 \mathrm{i}$ & $2.14 \mathrm{~h}$ & $2.08 \mathrm{~g}$ \\
1 & $2.08 \mathrm{i}$ & $2.12 \mathrm{j}$ & $2.23 \mathrm{~g}$ & $2.20 \mathrm{~h}$ & $2.19 \mathrm{gh}$ & $2.22 \mathrm{f}$ \\
2 & $2.18 \mathrm{~h}$ & $2.14 \mathrm{ij}$ & $2.26 \mathrm{~g}$ & $2.28 \mathrm{~g}$ & $2.26 \mathrm{fg}$ & $2.26 \mathrm{f}$ \\
3 & $2.22 \mathrm{gh}$ & $2.20 \mathrm{hi}$ & $2.30 \mathrm{fg}$ & $2.30 \mathrm{~g}$ & $2.27 \mathrm{f}$ & $2.28 \mathrm{f}$ \\
4 & $2.28 \mathrm{~g}$ & $2.23 \mathrm{gh}$ & $2.37 \mathrm{ef}$ & $2.33 \mathrm{~g}$ & $2.35 \mathrm{e}$ & $2.40 \mathrm{e}$ \\
5 & $2.35 \mathrm{f}$ & $2.29 \mathrm{~g}$ & $2.42 \mathrm{e}$ & $2.46 \mathrm{f}$ & $2.43 \mathrm{~d}$ & $2.46 \mathrm{e}$ \\
6 & $2.36 \mathrm{f}$ & $2.40 \mathrm{f}$ & $2.50 \mathrm{~d}$ & $2.53 \mathrm{e}$ & $2.45 \mathrm{~d}$ & $2.47 \mathrm{e}$ \\
7 & $2.56 \mathrm{e}$ & $2.59 \mathrm{e}$ & $2.84 \mathrm{c}$ & $2.90 \mathrm{~d}$ & $2.69 \mathrm{c}$ & $2.67 \mathrm{~d}$ \\
8 & $2.63 \mathrm{~d}$ & $2.67 \mathrm{~d}$ & $2.92 \mathrm{c}$ & $2.91 \mathrm{~d}$ & $2.72 \mathrm{c}$ & $2.75 \mathrm{~cd}$ \\
9 & $2.83 \mathrm{c}$ & $2.79 \mathrm{c}$ & $3.06 \mathrm{~b}$ & $3.08 \mathrm{c}$ & $2.93 \mathrm{~b}$ & $2.86 \mathrm{c}$ \\
10 & $2.94 \mathrm{~b}$ & $3.03 \mathrm{~b}$ & $3.21 \mathrm{a}$ & $3.15 \mathrm{~b}$ & $3.17 \mathrm{a}$ & $3.00 \mathrm{~b}$ \\
open & $3.12 \mathrm{a}$ & $3.14 \mathrm{a}$ & $3.24 \mathrm{a}$ & $3.27 \mathrm{a}$ & $3.19 \mathrm{a}$ & $3.22 \mathrm{a}$ \\
Mean \pm se & $2.456 \mathrm{E}$ & $2.468 \mathrm{D}$ & $2.622 \mathrm{~A}$ & $2.625 \mathrm{~A}$ & $2.564 \mathrm{~B}$ & $2.554 \mathrm{C}$ \\
& \pm 0.104 & \pm 0.107 & \pm 0.118 & \pm 0.119 & \pm 0.107 & \pm 0.100 \\
\hline
\end{tabular}

Means in the same row or the same column with the same letter (s) are not significantly differed according to Duncan's Multiple Range Test at 0.05 . 
In both seasons of the present study, data in Table (2) showed that fruit length is positively affected by honey bee activity on plum flowers. In 2012, Golden Japanese cv. showed mean fruit length was $1.95 \mathrm{~cm}$. in the self-pollinated flowers, while a single visit/ flower caused significant increment in fruit length $(2.08 \mathrm{~cm}$.), followed by significant continuous increment as the number of bee visits/ flower increased until it reached the highest significant fruit length as a result of 10 bee visits/ flower (a mean of $2.94 \mathrm{~cm}$.) which was insignificantly different from that of the open pollinated flowers $(3.12 \mathrm{~cm}$.). A similar response was observed in Hollywood and Santarosa cvs. in terms of fruit length as a result of a different number of bee visits/ flower.

Data in Table (3) reveal a continuous increment in fruit diameter during both seasons of investigation when flowers were exposed to 10 bee visits/ flower (3.53 \& 3.60 for Golden Japanese, $3.76 \& 3.68$ for Hollywood and $3.70 \& 3.57$ for Santarosa in 2012 and 2013, respectively), in comparison to self-pollinated flowers (2.27\& 2.31 for Golden Japanese, $2.42 \& 2.39$ for Hollywood and $2.50 \& 2.37$ for Santarosa in 2012 and 2013, respectively).

Table (3). Effect of number of bee visits/ flower on fruit diameter of three Plum varieties during two successive seasons, (20122013).

\begin{tabular}{lcccccc}
\hline \multicolumn{2}{l}{ No. of bees/ Golden Japanese } & \multicolumn{2}{c}{ Hollywood } & \multicolumn{2}{c}{ Santarosa } \\
Flower & $\mathbf{2 0 1 2}$ & $\mathbf{2 0 1 3}$ & $\mathbf{2 0 1 2}$ & $\mathbf{2 0 1 3}$ & $\mathbf{2 0 1 2}$ & $\mathbf{2 0 1 3}$ \\
\hline 0 & $2.27 \mathrm{k}$ & $2.31 \mathrm{j}$ & $2.42 \mathrm{de}$ & $2.39 \mathrm{k}$ & $2.50 \mathrm{j}$ & $2.37 \mathrm{j}$ \\
1 & $2.37 \mathrm{j}$ & $2.46 \mathrm{i}$ & $2.61 \mathrm{cde}$ & $2.55 \mathrm{j}$ & $2.53 \mathrm{j}$ & $2.58 \mathrm{i}$ \\
2 & $2.52 \mathrm{i}$ & $2.50 \mathrm{i}$ & $2.69 \mathrm{cde}$ & $2.71 \mathrm{i}$ & $2.65 \mathrm{i}$ & $2.70 \mathrm{~h}$ \\
3 & $2.60 \mathrm{~h}$ & $2.56 \mathrm{~h}$ & $2.78 \mathrm{cde}$ & $2.77 \mathrm{~h}$ & $2.73 \mathrm{~h}$ & $2.76 \mathrm{~h}$ \\
4 & $2.72 \mathrm{~g}$ & $2.65 \mathrm{~g}$ & $2.84 \mathrm{e}$ & $2.80 \mathrm{~h}$ & $2.81 \mathrm{~g}$ & $2.86 \mathrm{~g}$ \\
5 & $2.80 \mathrm{f}$ & $2.78 \mathrm{f}$ & $2.87 \mathrm{bcd}$ & $2.90 \mathrm{~g}$ & $2.88 \mathrm{f}$ & $2.92 \mathrm{fg}$ \\
6 & $2.83 \mathrm{f}$ & $2.86 \mathrm{e}$ & $2.97 \mathrm{bc}$ & $3.00 \mathrm{f}$ & $2.90 \mathrm{f}$ & $2.94 \mathrm{f}$ \\
7 & $3.07 \mathrm{e}$ & $3.11 \mathrm{~d}$ & $3.32 \mathrm{ab}$ & $3.37 \mathrm{e}$ & $3.20 \mathrm{e}$ & $3.18 \mathrm{e}$ \\
8 & $3.20 \mathrm{~d}$ & $3.29 \mathrm{c}$ & $3.48 \mathrm{a}$ & $3.46 \mathrm{~d}$ & $3.32 \mathrm{~d}$ & $3.38 \mathrm{~d}$ \\
9 & $3.38 \mathrm{c}$ & $3.32 \mathrm{c}$ & $3.52 \mathrm{a}$ & $3.59 \mathrm{c}$ & $3.43 \mathrm{c}$ & $3.49 \mathrm{c}$ \\
10 & $3.53 \mathrm{~b}$ & $3.60 \mathrm{~b}$ & $3.76 \mathrm{a}$ & $3.68 \mathrm{~b}$ & $3.70 \mathrm{~b}$ & $3.57 \mathrm{~b}$ \\
open & $3.66 \mathrm{a}$ & $3.70 \mathrm{a}$ & $3.81 \mathrm{a}$ & $3.83 \mathrm{a}$ & $3.74 \mathrm{a}$ & $3.77 \mathrm{a}$ \\
\multirow{2}{*}{ Mean \pm se } & $2.910 \mathrm{E}$ & $2.927 \mathrm{D}$ & $3.089 \mathrm{~A}$ & $3.088 \mathrm{~A}$ & $3.030 \mathrm{C}$ & $3.042 \mathrm{~B}$ \\
& \pm 0.132 & \pm 0.134 & \pm 0.135 & \pm 0.139 & \pm 0.126 & \pm 0.125 \\
\hline
\end{tabular}

Means in the same row or the same column with the same letter (s) are not significantly differed according to Duncan's Multiple Range Test at 0.05 .

In general, in self-pollination fruit dimensions were the highest in Santarosa followed by Hollywood and then Golden Japanese in the least. It clear that from recorded data in all number of honeybees visiting was more effective in Hollywood followed by Santarosa and the least effect on Golden Japanese.

According to Abdelaziz et al. (1999) open pollination in apple gave fruits of the broadest diameter. The above results go in line with Hassan et al. (2007) on plum, Yehia et al. (2008) on apple and El-Dereny, Sarah (2010) on apple and almond fruits.

3. Fruit weight (g.) and volume $\left(\mathrm{cm}^{3}{ }^{3}\right)$ :

It is evident from Table (4) and (5) that the three cultivars under open pollination gave the heaviest and largest fruits followed by 10 bee visits, during the two successive seasons.
Mean fruit weight of plum cvs. were significantly affected by the number of bee visits/ flower during both seasons of study. In 2012, the lowest significant mean of fruit weight was $19.93 \mathrm{~g}$. at zero bee visits/ flower but as the number of bee visits increased, there was a significant increment in the mean of fruit weight. Single bee visit/ flower caused a significant increase of 24.90 g. in fruit weight for Golden Japanese cv. and the highest significant fruit weight $80.85 \mathrm{~g}$. was recorded at 10 bee visits/ flower being insignificantly different from the flowers exposed to open pollination (mean fruit weight 84.00 g.). A similar trend was observed in 2013 for plum cvs. as fruit weight significantly increased with increasing the number of bee visits/ flower.

Table (4). Effect of number of bee visits/ flower on fruit weight of three Plum varieties during two successive seasons, (2012-2013).

\begin{tabular}{lcccccc}
\hline \multicolumn{2}{l}{ No. of bees/ Golden Japanese } & \multicolumn{2}{c}{ Hollywood } & \multicolumn{2}{c}{ Santarosa } \\
Flower & $\mathbf{2 0 1 2}$ & $\mathbf{2 0 1 3}$ & $\mathbf{2 0 1 2}$ & $\mathbf{2 0 1 3}$ & $\mathbf{2 0 1 2}$ & $\mathbf{2 0 1 3}$ \\
\hline 0 & $19.93 \mathrm{l}$ & $20.97 \mathrm{l}$ & 27.101 & $26.05 \mathrm{l}$ & $28.16 \mathrm{k}$ & $25.78 \mathrm{l}$ \\
1 & $24.90 \mathrm{k}$ & $26.04 \mathrm{k}$ & $33.54 \mathrm{k}$ & $31.56 \mathrm{k}$ & $31.07 \mathrm{j}$ & $32.61 \mathrm{k}$ \\
2 & $32.62 \mathrm{j}$ & $30.86 \mathrm{j}$ & $37.99 \mathrm{j}$ & $39.37 \mathrm{j}$ & $36.80 \mathrm{i}$ & $38.18 \mathrm{j}$ \\
3 & $35.90 \mathrm{i}$ & $34.81 \mathrm{i}$ & $49.05 \mathrm{i}$ & $48.48 \mathrm{i}$ & $43.49 \mathrm{~h}$ & $46.82 \mathrm{i}$ \\
4 & $41.75 \mathrm{~h}$ & $40.86 \mathrm{~h}$ & $55.63 \mathrm{~h}$ & $53.49 \mathrm{~h}$ & $54.28 \mathrm{~g}$ & $56.82 \mathrm{~h}$ \\
5 & $48.24 \mathrm{~g}$ & $45.41 \mathrm{~g}$ & $60.79 \mathrm{~g}$ & $62.96 \mathrm{~g}$ & $61.10 \mathrm{f}$ & $64.00 \mathrm{~g}$ \\
6 & $53.46 \mathrm{f}$ & $57.32 \mathrm{f}$ & $68.15 \mathrm{f}$ & $70.85 \mathrm{f}$ & $64.65 \mathrm{e}$ & $65.82 \mathrm{f}$ \\
7 & $61.63 \mathrm{e}$ & $64.11 \mathrm{e}$ & $76.92 \mathrm{e}$ & $77.99 \mathrm{e}$ & $69.79 \mathrm{~d}$ & $67.34 \mathrm{e}$ \\
8 & $67.26 \mathrm{~d}$ & $68.99 \mathrm{~d}$ & $80.23 \mathrm{~d}$ & $79.87 \mathrm{~d}$ & $76.77 \mathrm{c}$ & $74.42 \mathrm{~d}$ \\
9 & $76.29 \mathrm{c}$ & $75.53 \mathrm{c}$ & $82.96 \mathrm{c}$ & $83.80 \mathrm{c}$ & $76.75 \mathrm{c}$ & $79.10 \mathrm{c}$ \\
10 & $80.85 \mathrm{~b}$ & $83.77 \mathrm{~b}$ & $87.07 \mathrm{~b}$ & $85.97 \mathrm{~b}$ & $86.14 \mathrm{~b}$ & $82.54 \mathrm{~b}$ \\
open & $84.00 \mathrm{a}$ & $85.29 \mathrm{a}$ & $95.75 \mathrm{a}$ & $97.60 \mathrm{a}$ & $89.97 \mathrm{a}$ & $93.79 \mathrm{a}$ \\
Mean $\pm \mathrm{se}$ & $52.234 \mathrm{~F} 52.830 \mathrm{E} 62.932 \mathrm{~B} 63.164 \mathrm{~A} 59.914 \mathrm{D} 60.600 \mathrm{C}$ \\
& \pm 6.331 & \pm 6.555 & \pm 6.515 & \pm 6.709 & \pm 6.128 & \pm 6.094 \\
\hline
\end{tabular}

Means in the same row or the same column with the same letter (s) are not significantly differed according to Duncan's Multiple Range Test at 0.05 .

Fruit volume for the three tested plum cvs. showed a lighter volume for isolated flowers during 2012 and 2013. In 2012, the lowest mean significant fruit volume was $12.08 \mathrm{~cm}^{3}$ at zero bee visits/ flower for Golden Japanese and jumped to $79.58 \mathrm{~cm}^{3}$ at 10 bee visits/ flower. In 2013, such result was confirmed and fruit volume increased with the increase in the number of visits by bees. Meanwhile, open pollination differed significantly from 10 bee visits/ flower where the mean reached $86.77 \mathrm{~cm}^{3}$ and $87.40 \mathrm{~cm}^{3}$ in 2012 and 2013 seasons, respectively.

Previous results agree with those presented by Abdelaziz et al. (1999) who reported statistical differences in fruit weight as a result of different pollination treatments on apple. Also, these results are agreement with those obtained by Hassan et al. (2007) on plum and Stino et al. (2001) and Yehia et al. (2008) on apple and El-Dereny, Sarah (2010) on apple and almond fruits where the biggest fruit size was obtained with open pollination.

\section{Fruit T.S.S. \%:}

Data in Table (6) indicated that the three cultivars which exposed to open pollination treatment recorded the significantly highest total sugar values. Meanwhile, the three cultivars recorded the lowest total sugars under self-pollination ( 0 bee visits) treatment. 
Table (5). Effect of number of bee visits/ flower on fruit volume of three Plum varieties during two successive seasons, (2012-2013).

\begin{tabular}{lcccccc}
\hline \multicolumn{2}{l}{ No. of bees/ Golden Japanese } & \multicolumn{2}{c}{ Hollywood } & \multicolumn{2}{c}{ Santarosa } \\
Flower & $\mathbf{2 0 1 2}$ & $\mathbf{2 0 1 3}$ & $\mathbf{2 0 1 2}$ & $\mathbf{2 0 1 3}$ & $\mathbf{2 0 1 2}$ & $\mathbf{2 0 1 3}$ \\
\hline 0 & $12.08 \mathrm{l}$ & $13.44 \mathrm{l}$ & 17.291 & $17.08 \mathrm{j}$ & $18.56 \mathrm{l}$ & $16.25 \mathrm{l}$ \\
1 & $18.02 \mathrm{k}$ & $20.31 \mathrm{k}$ & $26.04 \mathrm{k}$ & $22.50 \mathrm{i}$ & $22.40 \mathrm{k}$ & $25.00 \mathrm{k}$ \\
2 & $27.71 \mathrm{j}$ & $26.25 \mathrm{j}$ & $32.71 \mathrm{j}$ & $35.83 \mathrm{~h}$ & $32.08 \mathrm{j}$ & $32.92 \mathrm{j}$ \\
3 & $32.50 \mathrm{i}$ & $31.25 \mathrm{i}$ & $42.09 \mathrm{i}$ & $41.25 \mathrm{~g}$ & $38.44 \mathrm{i}$ & $39.48 \mathrm{i}$ \\
4 & $37.44 \mathrm{~h}$ & $34.69 \mathrm{~h}$ & $46.25 \mathrm{~h}$ & $41.88 \mathrm{~g}$ & $44.25 \mathrm{~h}$ & $49.38 \mathrm{~h}$ \\
5 & $47.19 \mathrm{~g}$ & $44.58 \mathrm{~g}$ & $49.94 \mathrm{~g}$ & $53.69 \mathrm{f}$ & $51.00 \mathrm{~g}$ & $54.58 \mathrm{~g}$ \\
6 & $50.10 \mathrm{f}$ & $53.25 \mathrm{f}$ & $62.92 \mathrm{f}$ & $64.06 \mathrm{e}$ & $56.56 \mathrm{f}$ & $59.06 \mathrm{f}$ \\
7 & $57.08 \mathrm{e}$ & $58.65 \mathrm{e}$ & $67.94 \mathrm{e}$ & $71.25 \mathrm{~d}$ & $63.54 \mathrm{e}$ & $62.08 \mathrm{e}$ \\
8 & $63.75 \mathrm{~d}$ & $66.67 \mathrm{~d}$ & $75.25 \mathrm{~d}$ & $74.19 \mathrm{~d}$ & $68.75 \mathrm{~d}$ & $71.67 \mathrm{~d}$ \\
9 & $71.56 \mathrm{c}$ & $69.06 \mathrm{c}$ & $79.38 \mathrm{c}$ & $80.63 \mathrm{c}$ & $72.71 \mathrm{c}$ & $77.38 \mathrm{c}$ \\
10 & $79.58 \mathrm{~b}$ & $84.17 \mathrm{~b}$ & $92.19 \mathrm{~b}$ & $87.50 \mathrm{~b}$ & $88.75 \mathrm{~b}$ & $81.88 \mathrm{~b}$ \\
open & $86.77 \mathrm{a}$ & $87.40 \mathrm{a}$ & $97.33 \mathrm{a}$ & $100.00 \mathrm{a}$ & $92.17 \mathrm{a}$ & $93.88 \mathrm{a}$ \\
\multirow{2}{*}{ Mean \pm se } & $48.649 \mathrm{E} 49.142 \mathrm{D} 57.443 \mathrm{~A} 57.488 \mathrm{~A} 54.101 \mathrm{C}$ & $55.296 \mathrm{~B}$ \\
& \pm 6.930 & \pm 7.114 & \pm 7.469 & \pm 7.589 & \pm 6.969 & \pm 6.875 \\
\hline
\end{tabular}

Means in the same row or the same column with the same letter (s) are not significantly differed according to Duncan's Multiple Range Test at 0.05 .

The number of bee visits/ flower significantly affected T.S.S. content of plum cvs. during both years of study. In 2012, the lowest T.S.S. was recorded in fruits formed from self-pollinated flowers which were significantly different from those formed from flowers exposed to a single bee visit/ flower, 1.02 and $1.27 \%$, respectively, for Golden Japanese cv., 1.20 and 1.93\%, respectively, for Hollywood cv., 1.25 and $1.51 \%$, respectively, for Santarosa cv. Increase the number of bee visits/ flower reached maximum levels at 10 bee visits/ flower and at open pollination 13.18 and $15.29 \%$, respectively, for Golden Japanese cv., 14.77 and $16.11 \%$, respectively, for Hollywood cv., 14.35 and $15.64 \%$, respectively, for Santarosa cv. Same trend was observed in the second season of investigation.

Table (6). Effect of number of bee visits/ flower on fruit T.S.S. \% of three Plum varieties during two successive seasons, (2012-2013).

\begin{tabular}{lcccccc}
\hline \multicolumn{2}{l}{ No. of bees/ Golden Japanese } & \multicolumn{2}{c}{ Hollywood } & \multicolumn{2}{c}{ Santarosa } \\
Flower & $\mathbf{2 0 1 2}$ & $\mathbf{2 0 1 3}$ & $\mathbf{2 0 1 2}$ & $\mathbf{2 0 1 3}$ & $\mathbf{2 0 1 2}$ & $\mathbf{2 0 1 3}$ \\
\hline 0 & $1.02 \mathrm{l}$ & $1.07 \mathrm{l}$ & 1.201 & $1.13 \mathrm{l}$ & $1.25 \mathrm{l}$ & $1.11 \mathrm{l}$ \\
1 & $1.27 \mathrm{k}$ & $1.32 \mathrm{k}$ & $1.93 \mathrm{k}$ & $1.65 \mathrm{k}$ & $1.51 \mathrm{k}$ & $1.75 \mathrm{k}$ \\
2 & $2.25 \mathrm{j}$ & $2.12 \mathrm{j}$ & $2.51 \mathrm{j}$ & $2.77 \mathrm{j}$ & $2.37 \mathrm{j}$ & $2.60 \mathrm{j}$ \\
3 & $3.16 \mathrm{i}$ & $3.06 \mathrm{i}$ & $3.87 \mathrm{i}$ & $3.76 \mathrm{i}$ & $3.34 \mathrm{i}$ & $3.42 \mathrm{i}$ \\
4 & $4.45 \mathrm{~h}$ & $4.17 \mathrm{~h}$ & $5.18 \mathrm{~h}$ & $4.86 \mathrm{~h}$ & $4.73 \mathrm{~h}$ & $5.56 \mathrm{~h}$ \\
5 & $6.09 \mathrm{~g}$ & $5.85 \mathrm{~g}$ & $6.31 \mathrm{~g}$ & $6.87 \mathrm{~g}$ & $6.51 \mathrm{~g}$ & $7.08 \mathrm{~g}$ \\
6 & $7.43 \mathrm{f}$ & $7.74 \mathrm{f}$ & $8.37 \mathrm{f}$ & $8.58 \mathrm{f}$ & $7.97 \mathrm{f}$ & $8.14 \mathrm{f}$ \\
7 & $8.89 \mathrm{e}$ & $9.10 \mathrm{e}$ & $9.71 \mathrm{e}$ & $9.88 \mathrm{e}$ & $9.44 \mathrm{e}$ & $9.25 \mathrm{e}$ \\
8 & $10.07 \mathrm{~d}$ & $10.16 \mathrm{~d}$ & $11.27 \mathrm{~d}$ & $11.00 \mathrm{~d}$ & $10.40 \mathrm{~d}$ & $10.63 \mathrm{~d}$ \\
9 & $11.71 \mathrm{c}$ & $11.50 \mathrm{c}$ & $12.58 \mathrm{c}$ & $12.81 \mathrm{c}$ & $12.03 \mathrm{c}$ & $12.29 \mathrm{c}$ \\
10 & $13.18 \mathrm{~b}$ & $13.79 \mathrm{~b}$ & $14.77 \mathrm{~b}$ & $14.16 \mathrm{~b}$ & $14.35 \mathrm{~b}$ & $13.49 \mathrm{~b}$ \\
open & $15.29 \mathrm{a}$ & $15.42 \mathrm{a}$ & $16.11 \mathrm{a}$ & $16.21 \mathrm{a}$ & $15.64 \mathrm{a}$ & $15.89 \mathrm{a}$ \\
\multirow{2}{*}{ Mean \pm se } & $7.064 \mathrm{E}$ & $7.108 \mathrm{D}$ & $7.817 \mathrm{~A}$ & $7.805 \mathrm{~A}$ & $7.460 \mathrm{C}$ & $7.601 \mathrm{~B}$ \\
& \pm 1.391 & \pm 1.426 & \pm 1.475 & \pm 1.469 & \pm 1.439 & \pm 1.406 \\
\hline
\end{tabular}

Means in the same row or the same column with the same letter (s) are not significantly differed according to Duncan's Multiple Range Test at 0.05 .

Similar results were reported by Hassan et al. (2007) on plum where T.S.S. was affected with different pollination treatments and seem to agree with the findings of (Arafat et al., 1994; Abdelaziz et al., 1999; Stino et al., 2001; Yehia et al., 2008 and El-Dereny, Sarah, 2010) on apple.

\section{Fruit firmness (lb/in. $\left.{ }^{2}\right)$ :}

Table (7) revealed that, a highly significant negative relation was existed between fruit firmness and the number of bee visits and generally the fruit resulted in from open pollination treatment tended to have the lowest fruit firmness within both seasons.

During both 2012 and 2013 seasons, fruit firmness of the three plum cvs. was significantly higher as a result of low number of bee visits/ flower. A significant gradual decrease of fruit firmness was noticed as the number of bee visits/ flower increased. Ten bee visits/ flower significantly reduced fruit firmness than the other lower numbers of visits. The mean of fruit firmness was $1.54,1.32$ and $1.34 \mathrm{lb} / \mathrm{in}^{2}$ for Golden Japanese, Hollywood and Santarosa fruits in 2012, while the self-pollinated flowers showed the highest significant fruit firmness, followed by a single bee visit/ flower for the three studied cvs. Same trend was observed in 2013.

Table(7). Effect of number of bee visits/ flower on fruit firmness of three Plum varieties during two successive seasons,(2012-2013).

\begin{tabular}{lcccccc}
\hline \multicolumn{2}{l}{ No. of bees/ Golden Japanese } & \multicolumn{2}{c}{ Hollywood } & \multicolumn{2}{c}{ Santarosa } \\
Flower & $\mathbf{2 0 1 2}$ & $\mathbf{2 0 1 3}$ & $\mathbf{2 0 1 2}$ & $\mathbf{2 0 1 3}$ & $\mathbf{2 0 1 2}$ & $\mathbf{2 0 1 3}$ \\
\hline 0 & $9.91 \mathrm{a}$ & $9.71 \mathrm{a}$ & $8.91 \mathrm{a}$ & $9.46 \mathrm{a}$ & $7.93 \mathrm{a}$ & $9.58 \mathrm{a}$ \\
1 & $7.63 \mathrm{~b}$ & $7.60 \mathrm{~b}$ & $7.14 \mathrm{~b}$ & $7.33 \mathrm{~b}$ & $7.41 \mathrm{~b}$ & $7.20 \mathrm{~b}$ \\
2 & $6.65 \mathrm{c}$ & $6.88 \mathrm{c}$ & $6.35 \mathrm{c}$ & $6.13 \mathrm{c}$ & $6.46 \mathrm{c}$ & $6.26 \mathrm{c}$ \\
3 & $5.87 \mathrm{~d}$ & $5.98 \mathrm{~d}$ & $5.21 \mathrm{~d}$ & $5.27 \mathrm{~d}$ & $5.61 \mathrm{~d}$ & $5.49 \mathrm{~d}$ \\
4 & $4.90 \mathrm{e}$ & $5.04 \mathrm{e}$ & $4.31 \mathrm{e}$ & $4.59 \mathrm{e}$ & $4.46 \mathrm{e}$ & $4.24 \mathrm{e}$ \\
5 & $4.02 \mathrm{f}$ & $4.12 \mathrm{f}$ & $3.81 \mathrm{f}$ & $3.58 \mathrm{f}$ & $3.71 \mathrm{f}$ & $3.52 \mathrm{f}$ \\
6 & $3.38 \mathrm{~g}$ & $3.20 \mathrm{~g}$ & $2.93 \mathrm{~g}$ & $2.81 \mathrm{~g}$ & $3.12 \mathrm{~g}$ & $3.04 \mathrm{~g}$ \\
7 & $2.79 \mathrm{~h}$ & $2.69 \mathrm{~h}$ & $2.50 \mathrm{~h}$ & $2.41 \mathrm{~h}$ & $2.55 \mathrm{~h}$ & $2.60 \mathrm{~h}$ \\
8 & $2.34 \mathrm{i}$ & $2.29 \mathrm{i}$ & $1.97 \mathrm{i}$ & $2.01 \mathrm{i}$ & $2.20 \mathrm{i}$ & $2.10 \mathrm{i}$ \\
9 & $1.81 \mathrm{j}$ & $1.88 \mathrm{j}$ & $1.63 \mathrm{j}$ & $1.59 \mathrm{j}$ & $1.72 \mathrm{j}$ & $1.69 \mathrm{j}$ \\
10 & $1.54 \mathrm{k}$ & $1.43 \mathrm{k}$ & $1.32 \mathrm{k}$ & $1.37 \mathrm{k}$ & $1.34 \mathrm{k}$ & $1.47 \mathrm{k}$ \\
open & 1.281 & $1.21 \mathrm{k}$ & 1.031 & 1.061 & 1.161 & 1.111 \\
\multirow{2}{*}{ Mean \pm se } & $4.342 \mathrm{~A}$ & $4.334 \mathrm{~B}$ & $3.924 \mathrm{E}$ & $3.967 \mathrm{D}$ & $3.971 \mathrm{D}$ & $4.024 \mathrm{C}$ \\
& \pm 0.782 & \pm 0.786 & \pm 0.729 & \pm 0.763 & \pm 0.688 & \pm 0.756 \\
\hline
\end{tabular}

Means in the same row or the same column with the same letter (s) are not significantly differed according to Duncan's Multiple Range Test at 0.05 .

Previous findings emphasize that crosspollination resulted in softer fruits compared to the other tested pollination regimes. The above results agree with Hassan et al. (2007) on plum. Firmest fruits were those obtained from non-pollinated regime (Arafat et al., 1994; Stino et al., 2001; Yehia et al., 2008 and ElDereny, Sarah, 2010) on apple.

Plum is completely self-incompatible and must be cross-pollinated with pollen from a different plant variety. In planting an orchard, it is necessary to select compatible varieties whose blooming periods overlap.

This investigation concentrated on the relationship between bee activity on plum flowers and its impact on fruit set as well as certain main fruit characteristics under cross-pollination. Generally, it may be concluded from the obtained results that pollination is a limiting factor in fruit set. This work focused on studying the relationship between the number of bee visits and the extent of improvement that might happen in fruit characteristics. Hence, insufficient cross-pollination is one of the most important factors responsible for low productivity in plum (Hassan et al., 
2007 and Sapir et al., 2007) and El-Dereny, Sarah (2010) on apple and almond fruits.

It further indicated a significant benefit for Golden Japanese, Hollywood and Santarosa cvs. in respect of final fruit set as well as fruit characteristics including fruit weight, volume, length, diameter, firmness and T.S.S. as a result of increased honey bee visits/ flower. In addition, the fruit quality and grade improved with decrease in fruit firmness.

Based on the work of others (Free, 1993; Calzoni and Speranza, 1996; 1998; Delaplane and Mayer, 2000; Abdelaziz, et al., 2005; Guerra, 2010 and Guerra and Rodrigo, 2015) on plums, (Arafat et al., 1994; Abdelaziz et al., 1999; Stern et al., 2001; Stino et al., 2001 and Yehia et al., 2008) on apples and El-Dereny, Sarah (2010) on apple and almond, they presented that increasing bee activity would improve cross-pollination and, subsequently, fruit set and yield were increased.

It is recommended, therefore, that securing sufficient numbers of honeybee colonies prior to the flowering season of Golden Japanese, Hollywood and Santarosa plum cvs. secures high productivity in terms of fruit set and fruit characteristics which are regarded as the main components of productivity efficiency.

\section{REFERENCES}

Abdelaziz, Enaiat; Khalil, B.M. and Stino, G.R. (1999). Effect of various pollinizers on fruit characters of low chilling apple cultivars. Egypt J. Agric. Res., 77(2):791-804.

Abdelaziz, Y. S. G.; Desouky, I. M. and Nariman, M. Abou El-Nasr and Ali, M. M. (2005). Studies on sex compatibility of some plum cultivars. Research Bull., Ain Shams Univ., 1-15.

A.O.A.C (1985). Association of Official Agriculture Chemistry, Officaila Methods of Analysis. Washington, D.C., USA.

Arafat, A.M.; Guirguis, N.S. and Yehia, M.M. (1994). Effect of open and cross-pollination on fruit set and fruit quality of Anna apple. Annals Agric. Sci. Moshtohor, 32(4):2083-2096.

Calzoni, G. L. and Speranza, A. (1996). Pear and plum pollination: honey bees, bumble bees of both? Acta Hort., 423: 83-90.

Calzoni, G. L. and Speranza, A. (1998). Insect controlled pollination in Japanese plum (Prunus saliciana Lindl.). Scientia Hort., 72: 227-237.

Delaplane, K. S. and Mayer, D. F. (2000). Crop pollination by bees. CABI publishing, New York; pp.247-250.

Duncan, D. B. (1955). Multiple range and multiple Ftest. Biometrics, 11: 1-24.
El-Dereny, Sarah, H. (2010). Studies on cross pollination of apple and almond trees (Family: Rosaceae) by honeybee foragers (Apis mellifera L.). M.Sc. Thesis, Fac. Agric., Cairo Univ.

Freed, R.; Eienensmith, S. P.; Gutez, S.; Reicosky, D.; Smail, V. W. and Woldberg, P. (1989). User's Guide to MSTAT-C Analysis of Agronomic Research Experiments. Michigan state university, East Lansing, USA.

Free, J.B. (1993). Insect Pollination of Crops. Second Edition, Academic Press, London; pp.431-466.

Guerra, M.E.; Wünsch, A.; Rodrigo, J. and LópezCorrales, M. (2010). Influence of pollination on low fruit set in Japanese plum. Acta Hort., 874: 189-191.

Guerra, M.E. and Rodrigo, J. (2015). Japanese plum: A review. Scientia Hort., 197: 974-686.

Hassan, H. S. A.; Mostafa, E. A. M. and Enas, A. M. Ali (2007). Effect of self, open and cross pollination on fruit characteristics of some plum cultivars. J. Agric. \& Environ. Sci., 2(2): 118122.

Langridge, D. F. and Goodman, R. D. (1985). Honeybee pollination of Japanese plums (Prunus salicina Lindl. cv. Satsuma) in the Goulburn Valley, Victoria. Australian J. of Experimental Agri., 25(1): 227 - 230.

Sapir, G.; Goldway, M.; Shafir, S. and Stern, R. A. (2007). Multiple introduction of honeybee colonies increases cross pollination, fruit-set and yield of 'Black Diamond' Japanese plum (Prunus salicina Lindl.). J. Horti. Sci. \& Biotechnology, 82(4): 590-596.

Stern, R.A.; Eisikowitch, D. and Dag, A. (2001). Sequential introduction of honey bee colonies and doubling their density increases crosspollination, fruit set and yield in 'Red Delicious' apple. J. Hort. Sci. \& Biotechnology, 76(1):1723.

Stern, R.A.; Sapir, G.; Shafir, S.; Dag, A. and Goldway, M. (2007). The appropriate management of honey bee colonies for pollination of Rosaceae fruit trees in warm climates. Middle Eastern and Russian J. of Plant Sci. \& Biotechnology, 1(1): 13-19.

Stino, R.G.; Hegazy, E.S.; Yehia, T.A. and Hegazy, A.A. (2001). Bearing potential, fruit growth and quality of Anna apple in relation to bud positions and pollination regimes. Egypt. J. Hort., 28(3):291-303.

Yehia, T.A.; Abd Al-Fattah, M.A. and El-Dereny, Sarah, H. (2008). Effect of honeybee visits to apple flowers on fruit set and fruit characteristics. J. Biol. Chem. \& Environ. Sci., 3(2): 497-514. 


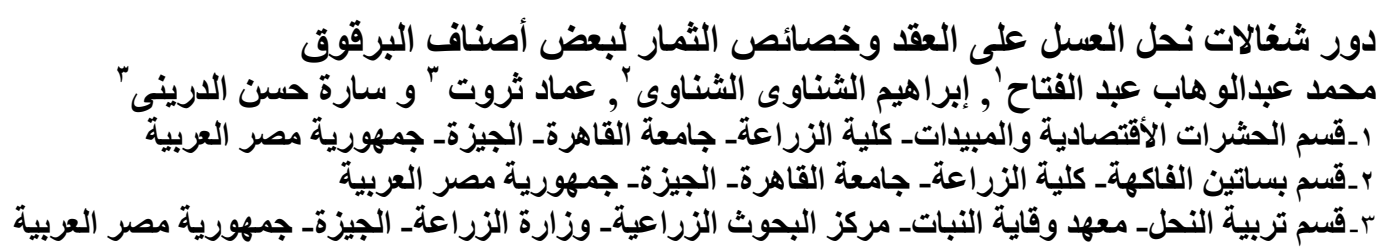

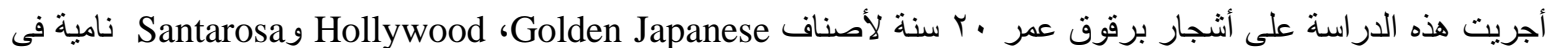

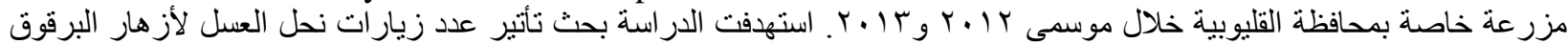

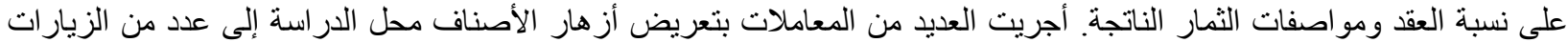

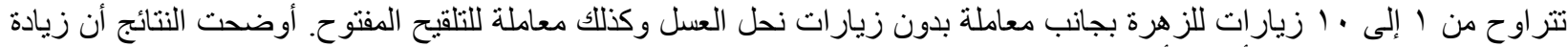

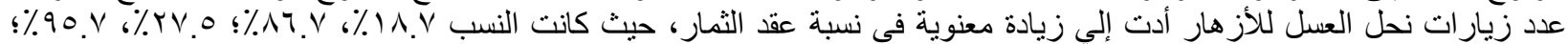

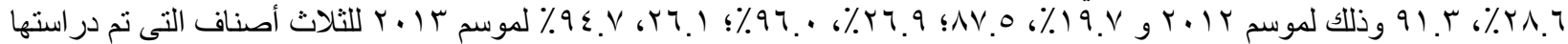

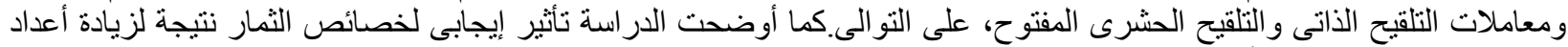

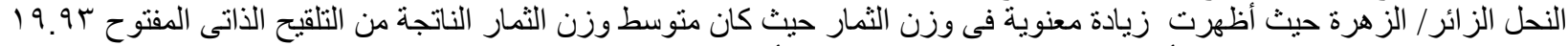

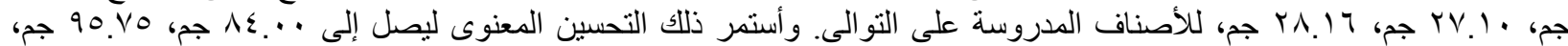

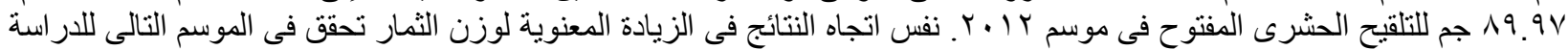

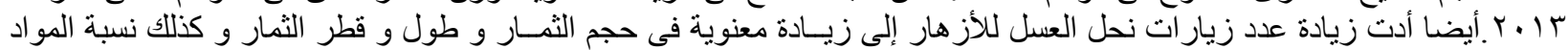

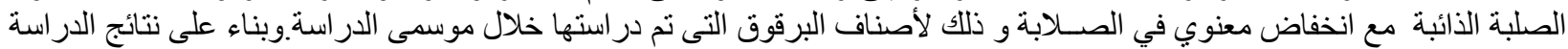

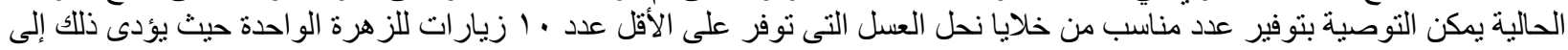

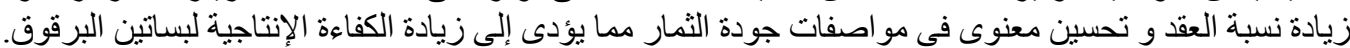
الكلمات الدالة: البرقوق، التلقيح، نحل العسل، عقد الثمار ، خصائص الثما لثمار. 